\title{
Does coupling to ADP ribosylation factor 6 explain differences between muscarinic and other receptors in interaction with $\beta$-adrenoceptor-mediated smooth muscle relaxation?
}

\author{
Betül R. Erdogan ${ }^{1}\left(\right.$ D $\cdot$ Martin C. Michel $^{2}$ (D)
}

Received: 3 February 2022 / Accepted: 10 February 2022 / Published online: 17 February 2022

(c) The Author(s) 2022

\begin{abstract}
Numerous studies in airways, ileum, and urinary bladder have demonstrated that relaxation by $\beta$-adrenoceptor agonists has lower potency and/or efficacy when contraction was elicited by muscarinic receptor agonists as compared to other G-proteincoupled receptors, $\mathrm{KCl}$, or basal tone, but the molecular mechanisms behind this relative resistance remain unclear. A paper by Huang et al. in this issue demonstrates that NAV2729, an inhibitor of ADP ribosylation factor 6, inhibits contraction of isolated blood vessels elicited by muscarinic receptor agonists, but not by $\alpha_{1}$-adrenoceptor agonists or KCl. Against this background, we discuss the role of ADP ribosylation factor 6 in cellular responses to G-protein-coupled receptor stimulation. While ADP ribosylation factor 6 apparently is the only promising molecular explanation for the relative resistance of smooth muscle contraction elicited by muscarinic agonists, the existing data are insufficient for a robust conclusion.
\end{abstract}

Keywords ADP ribosylation factor $6 \cdot \beta$-Adrenoceptor $\cdot$ G-Protein-coupled receptor $\cdot$ Muscarinic receptor $\cdot$ Contraction

Muscarinic receptors are important mediators of smooth muscle contraction in various tissues including airways, gut, and urinary bladder; this largely involves the $\mathrm{M}_{3}$ subtype but $\mathrm{M}_{2}$ receptors can also affect smooth muscle tone (Hegde and Eglen 1999). $M_{3}$ receptors typically couple to G-proteins of the $\mathrm{G}_{\mathrm{q} / 11}$ type leading to activation of a phospholipase C (PLC) (Caulfield and Birdsall 1998). Surprisingly, $\mathrm{M}_{3}$-mediated smooth muscle contraction is not explained by PLC activation, for instance in the bladder (Frazier et al. 2008), but alternative molecular mechanisms to elicit smooth muscle contraction have not been well-defined.

The potency and/or efficacy of $\beta$-adrenoceptor agonists to relax smooth muscle is lower when tested against muscarinic agonists such as carbachol than against agonists at other receptors, against passive tension or against receptorindependent contraction elicited by $\mathrm{KCl}$ (Dale et al. 2014). Such observations have been made in airways (Russel 1984;

Martin C. Michel

marmiche@uni-mainz.de

1 Department of Pharmacology, Faculty of Pharmacy, Izmir Katip Celebi University, Izmir, Turkey

2 Department of Pharmacology, Johannes Gutenberg University, Langenbeckstr. 1, 55131 Mainz, Germany
Raffestin et al. 1985; Ostrom and Ehlert 1999; Sarria et al. 2002; Naline et al. 2007), ileum (Ostrom and Ehlert 1999), and bladder (Longhurst and Levendusky 1999; Witte et al. 2011; Kanie et al. 2012) of multiple species including rat (Longhurst and Levendusky 1999; Michel and Sand 2009; Witte et al. 2011; Cernecka et al. 2014), guinea pig (Ostrom and Ehlert 1999), dog (Russel 1984), and human (Raffestin et al. 1985; Sarria et al. 2002; Naline et al. 2007; Kanie et al. 2012) and with agonists acting at histamine (Russel 1984; Raffestin et al. 1985; Ostrom and Ehlert 1999; Naline et al. 2007), 5-hydroxytryptamine (5-HT) (Michel and Sand 2009; Cernecka et al. 2014), bradykinin (Michel and Sand 2009; Cernecka et al. 2014), prostanoid receptors (Sarria et al. 2002), passive tone (Naline et al. 2007; Michel and Sand 2009; Cernecka et al. 2014), or KCl (Longhurst and Levendusky 1999; Michel and Sand 2009; Kanie et al. 2012). While most of the above studies have used general $\beta$-adrenoceptor agonists such as isoprenaline, similar findings have also been obtained with agonists selective for $\beta_{2^{-}}$ adrenoceptors such as formoterol, indacaterol, salbutamol, and salmeterol in human bronchi (Naline et al. 2007) or fenoterol in rat bladder (Erdogan et al. 2021) or selective for $\beta_{3}$-adrenoceptors such as TRK 380 in human bladder (Kanie et al. 2012) or KUC 7322 in rat bladder (Cernecka et al. 2014). However, it has remained elusive why smooth 
muscle contraction elicited by muscarinic receptor agonists is more resistant to relaxation by $\beta$-adrenoceptor agonists than that elicited by other stimuli. It appears logical that such selective resistance should be related to a signaling pathway activated preferentially by muscarinic receptors as compared to other receptors, but we are not aware of such signaling pathways.

A paper in this issue of the journal demonstrates that NAV2729, an inhibitor of ADP ribosylation factor 6 (ARF6), inhibits coronary vascular smooth muscle contraction elicited by the muscarinic agonists carbachol and methacholine but not that elicited by agonists at other receptors including $\alpha_{1}$-adrenoceptors, 5-HT, endothelin-1, or prostanoid TP receptors or those elicited by $\mathrm{KCl}$ (Huang et al. 2022). The same group had previously shown the existence of ARF6 expression human prostate smooth muscle tissue (Hennenberg et al. 2013) and that NAV2729 inhibited contraction in isolated human prostate strips by $\alpha_{1}$-adrenoceptor agonists, whereas that elicited by a prostanoid TP receptor agonist, endothelin-1 or by $\mathrm{KCl}$, was not inhibited (Yu et al. 2019). Furthermore, NAV2729 inhibited contraction in human prostate smooth muscle cells, and this was also observed in ARF6 knockout cells (Wang et al. 2021). Inhibition of ARF6 by NAV2729 inhibited contraction elicited by $\alpha_{1^{-}}$ adrenoceptor agonists in human prostate (Yu et al. 2019) but not porcine blood vessels (Huang et al. 2022). Interestingly, the inhibition of contraction in human prostate was accompanied by an inhibition of ARF6 in pull-down assays, while ARF6 was not activated by noradrenaline, phenylephrine, or methoxamine (Yu et al. 2019). The selective inhibition of muscarinic receptor responses in the blood vessels
(Huang et al. 2022) raises the possibility that coupling to ARF6 may be a mechanism that distinguishes inhibition by $\beta$-adrenoceptor agonists of responses to a muscarinic agonist as compared to those elicited by other means.

ARF6 is a small GTP-binding protein that contributes to several cellular processes including G-protein-coupled receptor (GPCR) trafficking, actin organization, and contractile response through diverse downstream component interaction (Fig. 1, Table 1). ARF6 function is modulated by two distinct components. Guanine nucleotide exchange factors (GEFs) mediate the activation of ARF6, whereas GTPaseactivating proteins (GAPs) mediate inhibition. NAV2729 interferes in the formation of ARF6-GEF complex to inhibit the ARF6 activation (Yamauchi et al. 2017).

ARF6 was shown to be a prerequisite component further promoting either clathrin- or caveolin-mediated pathway in agonist-induced endocytosis of several GPCRs such as $\beta$-adrenoceptor in adipocytes (Liu et al. 2010) and $\beta_{2^{-}}$ adrenoceptor in HEK293 cells (Claing et al. 2001; Lawrence et al. 2005; Macia et al. 2012); $\mathrm{M}_{2}$ muscarinic receptors in HeLa cells (Delaney et al. 2002), in JEG-3 human choriocarcinoma cells (Reiner and Nathanson 2008), and in HEK293 cells (Houndolo et al. 2005); the luteinizing hormone chorionic gonadotropin receptor in HEK 293 cells (Kanamarlapudi et al. 2012); angiotensin type 1 receptor (Houndolo et al. 2005; Cotton et al. 2007); $\mu$-opioid receptor (Rankovic et al. 2009); the vasopressin $\mathrm{V}_{2}$ receptor; and endothelin type B receptor (Houndolo et al. 2005) in HEK293 cells. Upon agonist stimulation, GPCR endocytosis was found mostly activated via ARF6-dependent pathway with some exceptions which show inhibitor regulatory effect
Fig. 1 Schematic drawing of ARF6-mediated cellular effects in GPCRs agonist stimulation. Dashed red arrow, negative regulatory effect; black arrow, positive regulatory effect; GAP, GTPase-activating proteins; GDP, guanosine diphosphate; GEF, guanine nucleotide exchange factors; GTP, guanosine triphosphate; $\uparrow$, increase; $\downarrow$, decrease; $\leftrightarrow$, no effect

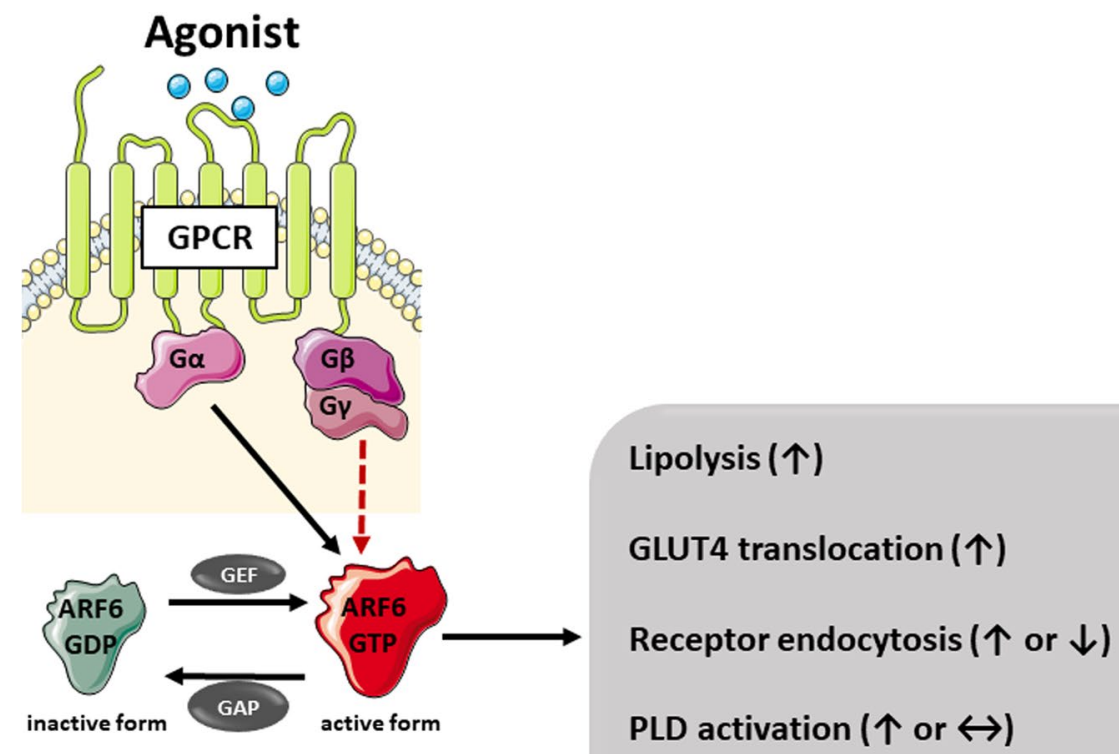

Smooth muscle contraction ( $\uparrow$ or $\leftrightarrow$ ) 
Table 1 ARF6-mediated responses through G-protein isoform/G-protein-coupled receptors

\begin{tabular}{|c|c|c|c|c|}
\hline Reference & Cell line/tissue preparation & $\begin{array}{l}\text { G-protein isoform/G-pro- } \\
\text { tein-coupled receptor }\end{array}$ & Main finding & ARF6-mediated effect \\
\hline Bose et al. (2001) & 3T3-L1 adipocytes & $\mathrm{G} \alpha 11$ & $\begin{array}{l}\text { Endothelin 1-induced } \\
\text { GLUT4 translocation }\end{array}$ & $\uparrow$ \\
\hline Bouschet et al. (2007) & HEK cells & Ca sensing receptor & Plasma membrane ruffling & $\uparrow$ \\
\hline Chakraborti et al. (2017) & $\begin{array}{l}\text { Human pulmonary artery } \\
\text { smooth muscle cells }\end{array}$ & Prostanoid TP receptor & $\begin{array}{l}\text { PLD2 and NADPH oxidase } \\
\text { activation }\end{array}$ & $\uparrow$ \\
\hline Chakraborti et al. (2018) & $\begin{array}{l}\text { Human pulmonary artery } \\
\text { smooth muscle cells }\end{array}$ & Endothelin receptor & $\begin{array}{l}\text { PLD and NADPH oxidase } \\
\text { activation }\end{array}$ & $\uparrow$ \\
\hline Claing et al. (2001) & HEK293 cells & $\beta_{2}$-adrenoceptor & $\begin{array}{l}\text { Agonist-induced receptor } \\
\text { endocytosis }\end{array}$ & $\uparrow$ \\
\hline Cotton et al. (2007) & HEK293 cells & Angiotensin type 1 receptor & $\begin{array}{l}\text { Agonist-induced membrane } \\
\text { ruffling and cell migration }\end{array}$ & $\uparrow$ \\
\hline Daher et al. (2008) & Endothelial cells & Endothelin $\mathrm{ET}_{\mathrm{B}}$ receptor & $\begin{array}{l}\text { Agonist-induced cell migra- } \\
\text { tion and angiogenesis }\end{array}$ & $\uparrow$ \\
\hline Davies et al. (2014) & 3T3-L1 adipocytes & Endothelin $\mathrm{ET}_{\mathrm{A}}$ receptor & Agonist-induced lipolysis & $\uparrow$ \\
\hline Delaney et al. (2002) & HeLa cells & $\mathrm{M}_{2}$ muscarinic receptor & $\begin{array}{l}\text { Agonist-induced receptor } \\
\text { endocytosis }\end{array}$ & $\downarrow$ \\
\hline Hennenberg et al. (2013) & $\begin{array}{l}\text { Human prostate smooth } \\
\text { muscle tissue }\end{array}$ & $\alpha_{1}$-adrenoceptor & Receptor desensitization & $\uparrow$ \\
\hline Herlemann et al. (2018) & $\begin{array}{l}\text { Human prostate smooth } \\
\text { muscle tissue }\end{array}$ & $\begin{array}{l}\alpha \text {-adrenoceptor } \\
\text { Prostanoid TP receptor } \\
\text { Endothelin receptor }\end{array}$ & Smooth muscle contraction & $\begin{array}{l}\uparrow \\
\uparrow \\
\uparrow\end{array}$ \\
\hline Houndolo et al. (2005) & HEK293 cells & $\begin{array}{l}\mathrm{M}_{2} \text { muscarinic receptor } \\
\text { Angiotensin type } 1 \text { receptor } \\
\text { Vasopressin } \mathrm{V}_{2} \text { receptor } \\
\text { Endothelin type B receptor } \\
\text { VIP receptor }\end{array}$ & $\begin{array}{l}\text { Agonist-induced receptor } \\
\text { endocytosis }\end{array}$ & $\begin{array}{l}\uparrow \\
\uparrow \\
\uparrow \\
\uparrow \\
\text { No effect }\end{array}$ \\
\hline Huang et al. (2022) & $\begin{array}{l}\text { Pig interlobar (ila) and coro- } \\
\text { nary (ca) artery smooth } \\
\text { muscle }\end{array}$ & $\begin{array}{l}\text { Muscarinic receptor } \\
\alpha_{1} \text {-Adrenoceptor } \\
5 \text {-HT receptor } \\
\text { Endothelin receptor } \\
\text { Prostanoid TP receptor }\end{array}$ & Smooth muscle contraction & $\begin{array}{l}\uparrow(c a), \text { no effect (ila) } \\
\text { No effect (ca and ila) } \\
\text { No effect (ca and ila) } \\
\text { No effect (ca and ila) } \\
\text { No effect (ca and ila) }\end{array}$ \\
\hline Johnson et al. (2006) & COS7 cells & $\begin{array}{l}\mathrm{N} 376 \mathrm{D} \text { mutant } 5-\mathrm{HT}_{2 \mathrm{~A}} \\
\text { receptor } \\
\mathrm{WT}_{5-\mathrm{HT}_{2 \mathrm{~A}}} \text { receptor } \\
\text { Purinergic } \mathrm{P}_{2 \mathrm{u}} \text { receptor } \\
\text { Thrombin PAR receptor } \\
\text { Gonadotropin-releasing } \\
\text { hormone receptor }\end{array}$ & PLD activation & $\begin{array}{l}\uparrow \\
\text { No effect } \\
\uparrow \\
\uparrow \\
\uparrow\end{array}$ \\
\hline Kanamarlapudi et al. (2012) & HEK 293 cells & $\begin{array}{l}\text { Luteinizing hormone chori- } \\
\text { onic gonadotropin receptor }\end{array}$ & Receptor internalization & $\uparrow$ \\
\hline Lawrence et al. (2005) & HEK293 cells & $\beta_{2}$-Adrenoceptor & Receptor internalization & $\uparrow$ \\
\hline $\begin{array}{l}\text { Lawrence and Birnbaum } \\
\text { (2001) }\end{array}$ & 3T3-L1 adipocytes & $\mathrm{G}_{\alpha q}$ & $\begin{array}{l}\text { Endothelin 1-induced } \\
\text { GLUT4 translocation }\end{array}$ & $\uparrow$ \\
\hline Le Stunff et al. (2000) & $\begin{array}{l}\text { Female Wistar rat myome- } \\
\text { trium }\end{array}$ & $\mathrm{G}_{\beta \gamma}$ & PLD activation & $\downarrow$ \\
\hline Liu et al. (2010) & 3T3-L1 adipocytes & $\beta$-Adrenoceptor & $\begin{array}{l}\text { Agonist-induced lipolysis } \\
\text { and endocytosis }\end{array}$ & $\uparrow$ \\
\hline Macia et al. (2012) & HEK293 cells & $\beta_{2}$-Adrenoceptor & Recycling of receptor & $\downarrow$ \\
\hline $\begin{array}{l}\text { Madziva and Birnbaumer } \\
\text { (2006) }\end{array}$ & HEK 293-T cells & Vasopressin $V_{2}$ receptor & $\begin{array}{l}\text { Agonist-induced receptor } \\
\text { endocytosis }\end{array}$ & No effect \\
\hline Mitchell et al. (2003) & COS7 cells & $\begin{array}{l}\mathrm{M}_{3} \text { muscarinic receptors } \\
\text { Purinergic } \mathrm{P}_{2 \mathrm{U}} \text { receptor } \\
\text { N376D mutant 5-HT } 2 \mathrm{~A} \\
\text { receptor }\end{array}$ & $\begin{array}{l}\text { PLD1/2 activation } \\
\text { PLD2 activation } \\
\text { PLD2 activation }\end{array}$ & $\begin{array}{l}\uparrow \\
\uparrow \\
\text { No effect }\end{array}$ \\
\hline
\end{tabular}


Table 1 (continued)

\begin{tabular}{lllll}
\hline Reference & Cell line/tissue preparation & $\begin{array}{l}\text { G-protein isoform/G-pro- } \\
\text { tein-coupled receptor }\end{array}$ & Main finding & ARF6-mediated effect \\
\hline Rankovic et al. (2009) & HEK293 cells & $\mu$-Opioid receptor & $\begin{array}{c}\text { Agonist-induced receptor } \\
\text { endocytosis }\end{array}$ & $\begin{array}{c}\uparrow \\
\end{array}$ \\
& & & PLD2 activation & \\
Reiner and Nathanson & JEG-3 human choriocarci- & $\mathrm{M}_{2}$ muscarinic receptor & Agonist-induced receptor & $\downarrow$ \\
(2008) & noma cells & $\mathrm{M}_{4}$ muscarinic receptor & endocytosis & No effect \\
Yu et al. (2019) & Human prostate smooth & $\alpha_{1}$-adrenoceptor & Smooth muscle contraction & $\uparrow$ \\
& muscle tissue & Prostanoid TP receptor & & No effect \\
& & Endothelin receptor & & No effect \\
\hline
\end{tabular}

of ARF6 in $\mathrm{M}_{2}$ muscarinic receptor (Delaney et al. 2002; Reiner and Nathanson 2008) and in $\beta_{2}$-adrenoceptor (Macia et al. 2012) internalization. Furthermore, VIP receptor internalization was not affected by ARF6 depletion (Houndolo et al. 2005). ARF6 involvement in trafficking did not exist for some receptors such as $\mathbf{M}_{4}$ muscarinic receptor (Reiner and Nathanson 2008) and vasopressin $\mathrm{V}_{2}$ receptor (Madziva and Birnbaumer 2006). ARF6 requirement in endocytosis was mostly demonstrated in agonist-induced settings, which may not reflect the ARF6 function for basal condition for the same receptor (Cotton et al. 2007). Moreover, ARF6 involvement of muscarinic receptor internalization has mostly been studied with the $\mathrm{M}_{2}$ subtype because of the well-defined, clathrin-dependent pathway-mediated internalization of $\mathbf{M}_{1}$, $\mathrm{M}_{3}$, and $\mathrm{M}_{4}$ receptors (Reiner and Nathanson 2008).

Phospholipase D (PLD) is known to be involved in smooth muscle contraction through PKC activation but its contribution in urinary bladder contraction was proposed to be minor (Frazier et al. 2008). ARF6-mediated PLD activation was reported by several researchers in in vivo animal (Le Stunff et al. 2000) and in vitro cultured cell line studies (Mitchell et al. 2003; Johnson et al. 2006; Rankovic et al. 2009; Chakraborti et al. 2017; Charles et al. 2018). In human pulmonary artery smooth muscle cells (HPASMCs), stimulation of prostanoid TP receptor stimulates cytohesin-1 coupling to ARF6 which further leads to PLD2 isoform and subsequent NADPH oxidase activation (Chakraborti et al. 2017). In HPASMCs, involvement of ARF6 in endothelin1-induced PLD and NADPH oxidase activation was shown by same study group (Chakraborti et al. 2018). ARF6 was shown to be involved in PLD activation in N376D mutant $5-\mathrm{HT}_{2 \mathrm{~A}}$-stimulated PLD activation but not in mediated via WT 5- $-\mathrm{HT}_{2 \mathrm{~A}}$ stimulation (Johnson et al. 2006). This study also showed the sensitivity of other class A GPCRs which contain DPxxY motif such as purinergic $\mathrm{P}_{2 u}$, thrombin PAR, and gonadotropin-releasing hormone receptor to ARF6 for further PLD activation in COS7 cells (Johnson et al. 2006). In the same cell line, agonist-stimulated $\mathrm{M}_{3}$ activation induced both PLD1/2 activation through ARF6-mediated pathway, whereas PLD2 activation was found linked to PKC and ARF6 in purinergic $\mathrm{P}_{2 \mathrm{U}}$ receptor and to only $\mathrm{PKC}$ in N376D mutant 5- $\mathrm{HT}_{2 \mathrm{a}}$ receptor (Mitchell et al. 2003). ARF6 is involved in the promotion of prostate smooth muscle contraction. Inhibition of ARF6 activation by cytohesin (a GEF) inhibitor resulted in reduced noradrenaline, phenylephrine-, thromboxane $\mathrm{A}_{2^{-}}$, and endothelin-1- and endothelin3 -induced contraction (Herlemann et al. 2018). In vascular smooth muscle cell, both ARF1 and ARF6 are involved in actin polymerization which subsequently migrate and proliferate but only ARF1 affected contractile responses (Charles et al. 2018). However, in a latter study, ARF6 was found to promote contraction and proliferation in human prostate stromal cells (WPMY-1) (Wang et al. 2021).

ARF6 activation interrupts the recycling of $\beta_{2}$ adrenoceptors and lead desensitization of receptor in HEK293 cells (Macia et al. 2012); similarly, it is postulated that ARF6 may involve in $\alpha_{1}$-adrenoceptor desensitization in human prostate tissue (Hennenberg et al. 2013). In contrast, ARF6-mediated endocytosis was suggested beneficial in development of opioid tolerance through preventing receptor desensitization HEK293 cells (Rankovic et al. 2009).

Other effects of ARF6 include the calcium-sensing receptor-mediated plasma membrane ruffling which is required for chemotaxis in HEK cells (Bouschet et al. 2007). In endothelial cells, endothelin $\mathrm{ET}_{\mathrm{B}}$ receptor stimulation by endothelin 1 results in ARF6 activation which facilitates cell migration via actin reorganization. Moreover, endothelin 1 stimulation did not promote capillary tube formation in ARF6 depleted cells which indicates ARF6 involvement in angiogenesis (Daher et al. 2008). ARF6 also has regulatory effects on metabolic pathway. Depletion of ARF6 resulted in inhibition of isoproterenol-induced lipolysis in 3T3-L1 adipocytes. ARF6 mRNA and protein level was found higher in WAT tissue of $o b / o b$ mice compared to obesity resistance mice (Liu et al. 2010). In 3T3-L1 adipocytes, endothelin $\mathrm{ET}_{\mathrm{A}}$ receptor-mediated lipolysis was found to be dependent downstream ARF6-ERK1/2 signaling (Davies et al. 2014). Additionally, endothelin 1 stimulated GLUT4 translocation through heterotrimetric $\mathrm{G}_{\mathrm{q}}$ protein signaling pathway activated by ARF6 in 3T3-L1 adipocytes (Bose et al. 2001; 
Lawrence and Birnbaum 2001) and specifically $\mathrm{G}_{\alpha 11}$ isoform of $\mathrm{G}_{\alpha \mathrm{\alpha}}$ family.

Taken together, the above data demonstrate that ARF6 is involved in cellular processes and is activated by cellular effects stimulated by various GPCR, including smooth muscle contraction. Within a given tissue, the involvement of ARF6 in pathways leading to smooth muscle contraction, e.g., in arteries or prostate, appears to be preferential for some GPCR (muscarinic receptors and $\alpha_{1}$-adrenoceptors, respectively) over others apparently coupling to the same G-proteins. Some of these data are in line with the hypothesis that coupling to ARF6 may explain the relative resistance of smooth muscle contraction elicited by muscarinic receptors as compared to other GPCR or receptor-independent contraction such as receptor desensitization to relaxation by $\beta$-adrenoceptor agonists. However, not all data support this hypothesis. Thus, the role of ARF6 in this phenomenon cannot be considered proven, but it remains as a reasonable molecular candidate to explain the resistance of muscarinic receptor-mediated smooth muscle contraction against relaxation. Further studies at the molecular level are required to further explore this, specifically studies in which the role of agonists at various GPCR is compared quantitatively.

Acknowledgements The figure was generated by using Servier Medical Art by Servier licensed under a Creative Commons Attribution 3.0 unported license. http://smart.servier.com.

Author contribution MCM conceptualized the idea. BRE performed the literature search. Both BRE and MCM drafted and revised the manuscript and approved the final version.

Funding Open Access funding enabled and organized by Projekt DEAL.

\section{Declarations}

Conflict of interest The authors declare no competing interests.

Open Access This article is licensed under a Creative Commons Attribution 4.0 International License, which permits use, sharing, adaptation, distribution and reproduction in any medium or format, as long as you give appropriate credit to the original author(s) and the source, provide a link to the Creative Commons licence, and indicate if changes were made. The images or other third party material in this article are included in the article's Creative Commons licence, unless indicated otherwise in a credit line to the material. If material is not included in the article's Creative Commons licence and your intended use is not permitted by statutory regulation or exceeds the permitted use, you will need to obtain permission directly from the copyright holder. To view a copy of this licence, visit http://creativecommons.org/licenses/by/4.0/.

\section{References}

Bose A, Cherniack AD, Langille SE, Nicoloro SM, Buxton JM, Park JG, Chawla A, Czech MP (2001) Go11 signaling through ARF6 regulates F-actin mobilization and GLUT4 glucose transporter translocation to the plasma membrane. Mol Cell Biol 21:5262-5275

Bouschet T, Martin S, Kanamarlapudi V, Mundell S, Henley JM (2007) The calcium-sensing receptor changes cell shape via a $\beta$-arrestin-1-ARNO-ARF6-ELMO protein network. J Cell Sci 120:2489-2497

Caulfield MP, Birdsall NJM (1998) International Union of Pharmacology. XVII. Classification of muscarinic acetylcholine receptors. Pharmacol Rev 50:279-290

Cernecka H, Sand C, Michel MC (2014) The odd sibling: features of $\beta_{3}$-adrenoceptor pharmacology. Mol Pharmacol 86:479-484

Chakraborti S, Sarkar J, Chowdhury A, Chakraborti T (2017) Role of ADP ribosylation factor6- cytohesin1- phospholipase D signaling axis in U46619 induced activation of NADPH oxidase in pulmonary artery smooth muscle cell membrane. Arch Biochem Biophys 633:1-14

Chakraborti S, Sarkar J, Bhuyan R, Chakraborti T (2018) Role of catechins on ET-1-induced stimulation of PLD and NADPH oxidase activities in pulmonary smooth muscle cells: determination of the probable mechanism by molecular docking studies. Biochem Cell Biol 96:417-432

Charles R, Bourmoum M, Claing A (2018) ARF GTPases control phenotypic switching of vascular smooth muscle cells through the regulation of actin function and actin dependent gene expression. Cell Signal 46:64-75

Claing A, Chen W, Miller WE, Vitale N, Moss J, Premont RT, Lefkowitz RJ (2001) $\beta$-Arrestin-mediated ADP-ribosylation factor 6 activation and $\beta 2$-adrenergic receptor endocytosis. J Biol Chem 276:42509-42513

Cotton M, Boulay P-L, Houndolo T, Vitale N, Pitcher JA, Claing A (2007) Endogenous ARF6 interacts with Rac1 upon angiotensin II stimulation to regulate membrane ruffling and cell migration. Mol Biol Cell 18:501-511

Daher Z, Noël J, Claing A (2008) Endothelin-1 promotes migration of endothelial cells through the activation of ARF6 and the regulation of FAK activity. Cell Signal 20:2256-2265

Dale PR, Cernecka H, Schmidt M, Dowing M, Charlton SJ, Michel MC (2014) The pharmacological rationale for combining muscarinic receptor antagonists and $\mathrm{B}$-adrenoceptor agonists in the treatment of airway and bladder disease. Curr Opin Pharmacol 16C:31-42

Davies JC, Bain SC, Kanamarlapudi V (2014) ADP-ribosylation factor 6 regulates endothelin-1-induced lipolysis in adipocytes. Biochem Pharmacol 90:406-413

Delaney KA, Murph MM, Brown LM, Radhakrishna H (2002) Transfer of M2 muscarinic acetylcholine receptors to clathrin-derived early endosomes following clathrin-independent endocytosis. J Biol Chem 277:33439-33446

Erdogan BR, Yesilyurt ZE, Arioglu-Inan E, Michel MC (2021) Validation of fenoterol to study $\beta_{2}$-adrenoceptor function in the rat urinary bladder. Pharmacology 107:116-121

Frazier EP, Peters SLM, Braverman AS, Ruggieri MR Sr, Michel MC (2008) Signal transduction underlying control of urinary bladder smooth muscle tone by muscarinic receptors and B-adrenoceptors. Naunyn-Schmiedebergs Archives of Pharmacology 377:449-462

Hegde SS, Eglen RM (1999) Muscarinic receptor subtypes modulating smooth muscle contractility in the urinary bladder. Life Sci 64:419-428

Hennenberg M, Miersch J, Rutz B, Strittmatter F, Waidelich R, Stief CG, Gratzke C (2013) Noradrenaline induces binding of Clathrin 
light chain A to $\alpha 1$-adrenoceptors in the human prostate. Prostate 73:715-723

Herlemann A, Keller P, Schott M, Tamalunas A, Ciotkowska A, Rutz B, Wang Y, Yu Q, Waidelich R, Strittmatter F (2018) Inhibition of smooth muscle contraction and ARF6 activity by the inhibitor for cytohesin GEFs, secinH3, in the human prostate. American Journal of Physiology-Renal Physiology 314:F47-F57

Houndolo T, Boulay P-L, Claing A (2005) G protein-coupled receptor endocytosis in ADP-ribosylation factor 6-depleted cells. J Biol Chem 280:5598-5604

Huang R, Li B, Tamalunas A, Waidelich R, Stief CG, Hennenberg $M$ (2022) Inhibition of neurogenic contractions in renal arteries and of cholinergic contractions in coronary arteries by the presumed inhibitor of ADP-ribsolytion factor 6, NAV2729. Naunyn Schmiedeberg's Arch Pharmacol. https://doi.org/10.1007/ s00210-022-02218-2

Johnson MS, Robertson DN, Holland PJ, Lutz EM, Mitchell R (2006) Role of the conserved NPxxY motif of the 5-HT2A receptor in determining selective interaction with isoforms of ADP-ribosylation factor (ARF). Cell Signal 18:1793-1800

Kanamarlapudi V, Thompson A, Kelly E, Bernal AL (2012) ARF6 activated by the LHCG receptor through the cytohesin family of guanine nucleotide exchange factors mediates the receptor internalization and signaling. J Biol Chem 287:20443-20455

Kanie S, Otsuka A, Yoshikawa S, Morimoto T, Hareyama N, Okazaki S, Kobayashi R, Hasebe K, Nakao K, Hayashi R, Mochizuki H, Matsumoto R, Ozono S (2012) Pharmacological effect of TRK380 , a novel selective human 33 -adrenoceptor agonist, on mammalian detrusor strips. Urology 79:744.e741-744.e747

Lawrence JTR, Birnbaum MJ (2001) ADP-ribosylation factor 6 delineates separate pathways used by endothelin 1 and insulin for stimulating glucose uptake in 3T3-L1 adipocytes. Mol Cell Biol 21:5276-5285

Lawrence J, Mundell SJ, Yun H, Kelly E, Venkateswarlu K (2005) Centaurin- $\alpha 1$, an ADP-ribosylation factor 6 GTPase activating protein, inhibits $\beta 2$-adrenoceptor internalization. Mol Pharmacol 67:1822-1828

Le Stunff H, Dokhac L, Bourgoin S, Bader M-F, Harbon S (2000) Phospholipase $\mathrm{D}$ in rat myometrium: occurrence of a membranebound ARF6 (ADP-ribosylation factor 6)-regulated activity controlled by $\beta \gamma$ subunits of heterotrimeric G-proteins. Biochemical Journal 352:491-499

Liu Y, Zhou D, Abumrad NA, Su X (2010) ADP-ribosylation factor 6 modulates adrenergic stimulated lipolysis in adipocytes. Am J Physiol Cell Physiol 298:C921-C928

Longhurst PA, Levendusky M (1999) Pharmacological characterization of $\beta$-adrenoceptors mediating relaxation of the rat urinary bladder in vitro. Br J Pharmacol 127:1744-1750

Macia E, Partisani M, Paleotti O, Luton F, Franco M (2012) Arf6 negatively controls the rapid recycling of the $\beta 2$ adrenergic receptor. $\mathrm{J}$ Cell Sci 125:4026-4035

Madziva MT, Birnbaumer M (2006) A role for ADP-ribosylation factor 6 in the processing of G-protein-coupled receptors. J Biol Chem 281:12178-12186
Michel MC, Sand C (2009) Effect of pre-contraction on B-adrenoceptor-mediated relaxation of rat urinary bladder. World J Urol 27:711-715

Mitchell R, Robertson DN, Holland PJ, Collins D, Lutz EM, Johnson MS (2003) ADP-ribosylation factor-dependent phospholipase $\mathrm{D}$ activation by the M3 muscarinic receptor. J Biol Chem 278:33818-33830

Naline E, Trifilieff A, Fairhurst RA, Advenier C, Molimard M (2007) Effect of indacaterol, a novel long-acting $\beta_{2}$-agonist, on isolated human bronchi. Eur Respir J 29:575-581

Ostrom RS, Ehlert FJ (1999) Cross-functional antagonism between isoproterenol and M 2 muscarinic receptors in guinea pig ileum and trachea. J Pharmacol Exp Ther 288:969-976

Raffestin B, Cerrina J, Boullet C, Labat C, Benveniste J, Brink C (1985) Response and sensitivity of isolated human pulmonary muscle preparations to pharmacological agents. J Pharmacol Exp Ther 233:186-194

Rankovic M, Jacob L, Rankovic V, Brandenburg L-O, Schröder H, Höllt V, Koch T (2009) ADP-ribosylation factor 6 regulates muopioid receptor trafficking and signaling via activation of phospholipase D2. Cell Signal 21:1784-1793

Reiner C, Nathanson NM (2008) The internalization of the M2 and M4 muscarinic acetylcholine receptors involves distinct subsets of small G-proteins. Life Sci 82:718-727

Russel JA (1984) Differential inhibitory effect of isoproterenol on contractions of canine airways. J Appl Physiol 57:801-807

Sarria B, Naline E, Zhang Y, Cortijo J, Molimard M, Moreau J, Therond P, Advenier C, Morcillo EJ (2002) Muscarinic $\mathrm{M}_{2}$ receptors in acetylcholine-isoproterenol functional antagonism in human isolated bronchus. Am J Physiol 283:L1125-L1132

Wang R, Schneider S, Keppler OT, Li B, Rutz B, Ciotkowska A, Stief CG, Hennenberg M (2021) ADP ribosylation factor 6 promotes contraction and proliferation, suppresses apoptosis and Is specifically Inhibited by NAV2729 in prostate stromal cells. Mol Pharmacol 100:356-371

Witte LPW, de Haas N, Mammen M, Stangeland EL, Steinfeld T, Aiyar J, Michel MC (2011) Muscarinic receptor subtypes and signalling involved in the attenuation of isoprenaline-induced rat urinary bladder relaxation. Naunyn Schmiedebergs Arch Pharmacol 384:555-563

Yamauchi Y, Miura Y, Kanaho Y (2017) Machineries regulating the activity of the small GTPase Arf6 in cancer cells are potential targets for developing innovative anti-cancer drugs. Advances in Biological Regulation 63:115-121

Yu Q, Gratzke C, Wang R, Li B, Kuppermann P, Herlemann A, Tamalunas A, Wang Y, Rutz B, Ciotkowska A, Wang X, Strittmatter F, Waidelich R, Stief CG, Hennenberg M (2019) A NAV2729sensitive mechanism promotes adrenergic smooth muscle contraction and growth of stromal cells in the human prostate. J Biol Chem 294:12231-12249

Publisher's note Springer Nature remains neutral with regard to jurisdictional claims in published maps and institutional affiliations. 